\title{
COPPER, NICKEL AND ZINC REMOVAL BY PEANUT HULLS: BATCH AND COLUMN STUDIES IN MONO, TRI-COMPONENT SYSTEMS AND WITH REAL EFFLUENT
}

\author{
F.D. OLIVEIRA \\ A.C. SOARES \\ O.M. FREITAS \\ S.A. FIGUEIREDO*
}

Received: 24/02/10

Accepted: $30 / 06 / 10$

\author{
REQUIMTE / Instituto Superior de Engenharia do Porto \\ Rua Dr. António Bernardino de Almeida, 431 \\ 4200 - 072 Porto, Portugal
}

*to whom all correspondence should be addressed:

e-mail: saf@isep.ipp.pt

\begin{abstract}
The main goal of this research study was the removal of $\mathrm{Cu}(\mathrm{II}), \mathrm{Ni}(\mathrm{II})$ and $\mathrm{Zn}(\mathrm{II})$ from aqueous solutions using peanut hulls. This work was mainly focused on the following aspects: chemical characterization of the biosorbent, kinetic studies, study of the $\mathrm{pH}$ influence in mono-component systems, equilibrium isotherms and column studies, both in mono and tri-component systems, and with a real industrial effluent from the electroplating industry.

The chemical characterization of peanut hulls showed a high cellulose $(44.8 \%)$ and lignin $(36.1 \%)$ content, which favours biosorption of metal cations.

The kinetic studies performed indicate that most of the sorption occurs in the first 30 min for all systems. In general, a pseudo-second order kinetics was followed, both in mono and tri-component systems. The equilibrium isotherms were better described by Freundlich model in all systems. Peanut hulls showed higher affinity for copper than for nickel and zinc when they are both present. The $\mathrm{pH}$ value between 5 and 6 was the most favourable for all systems.

The sorbent capacity in column was 0.028 and $0.025 \mathrm{mmol} \mathrm{g}^{-1}$ for copper, respectively in mono and tri-component systems. A decrease of capacity for copper (50\%) was observed when dealing with the real effluent. The Yoon-Nelson, Thomas and Yan's models were fitted to the experimental data, being the latter the best fit.
\end{abstract}

KEYWORDS: biosorption, copper, equilibrium, fixed-bed column, kinetics, metal removal, nickel, peanut hulls, real industrial effluent, zinc.

\section{INTRODUCTION}

The water contamination by toxic metals through the discharge of industrial wastewaters is a worldwide environmental problem. The industries responsible for the discharge of wastewaters containing metals are mining and mineral processing, pigment manufacture, painting and photographic industries, metal-working and finishing processes. Since metals are nonbiodegradable, and may be bio-accumulated in living tissues, their removal from wastewaters is nowadays legally imposed (Sud et al., 2008).

The main techniques used for metals removal include chemical precipitation, electrolytic and membrane processes, ion exchange and adsorption. Even though these methods are efficient, some of them have found their application limited. Precipitation processes generate large quantity of sludge, which needs further treatment and disposal. The high operational costs, particularly due to the high energy consumption associated with electrolytic and membrane processes, limit their use, moreover the secondary wastes generated are sometimes difficult to treat. Although the sorption processes are efficient, they have their application limited by the high cost of ion exchange resins and activated carbon, the most used sorbents. 
The biosorbents can usually be obtained free of charge from the respective producers since they sometimes present disposal problems. They are cheaper than ion exchange resins and activated carbon because the only costs to be considered are those of transport and grinding. Several biosorbents from vegetable source have been tested for the removal of heavy metals, mainly agricultural wastes. Agricultural materials, particularly those containing cellulose, show potential metal biosorption capacity, namely rice and wheat husks, coconut, walnut and almond shells, maize corn cob, soybean hulls and grape stalks (Sud et al., 2008).

Peanut hulls, one of the most abundant food industry waste products, are a natural low cost material able to fix metal ions. This material may be a potential alternative to commonly used sorbents, with a cost of $0.0015 \$ \mathrm{dm}^{-3}$, estimated by Brown et al. (2000).

The main purpose of this study was the removal of copper (II), nickel (II) and zinc (II) from aqueous solutions, using peanut hulls. This work was mainly focused on the comparison of batch and column studies for mono and tri-component systems. One of the challenges in the treatment of real industrial wastewater is their complexity, often containing several metals and other chemical compounds. The material was also tested using a real effluent from the metal-plating industry, which is innovative.

\section{MATERIALS AND METHODS}

\subsection{Materials}

The peanut hulls were ground and sieved, then they were washed with desionised water for fines removal and dried at $40^{\circ} \mathrm{C}$. The grain size selected for this experimental work was $1.0-2.0 \mathrm{~mm}$ in order to avoid excessive head losses in the packed column experiments.

Analytical grade salts $\left(\mathrm{Cu}\left(\mathrm{NO}_{3}\right)_{2} \cdot 2 \frac{1}{2} \mathrm{H}_{2} \mathrm{O}, \mathrm{Ni}\left(\mathrm{NO}_{3}\right)_{2} \cdot 6 \mathrm{H}_{2} \mathrm{O}, \mathrm{Zn}\left(\mathrm{NO}_{3}\right)_{2} \cdot 4 \mathrm{H}_{2} \mathrm{O}\right)$ were used to prepare the metal solutions - $20 \mathrm{mg} \mathrm{L}^{-1}$ concentration for $\mathrm{Cu}(\mathrm{II}), \mathrm{Ni}(\mathrm{II})$ and $\mathrm{Zn}(\mathrm{II})$. The $\mathrm{pH}$ of each solution was measured and adjusted to the desired value using diluted solutions of $\mathrm{HCl}$ and $\mathrm{NaOH}$. During the experiments there was no concern in order to control the solution $\mathrm{pH}$ and no ionic strength was imposed, like in other research works (Reddad et al., 2002).

The real effluent from the metal-plating industry was obtained after a pre-treatment (neutralization with $\mathrm{H}_{2} \mathrm{SO}_{4} / \mathrm{NaOH}$ and $\mathrm{NaClO}$ oxidation) performed locally. Its characterization can be summarized as follows: neutral $\mathrm{pH}$ (7.05), high conductivity $\left(2600 \mu \mathrm{S} \mathrm{cm} \mathrm{cm}^{-1}\right), 730.9 \mathrm{mV}$ oxidation-reduction potential, low cyanides concentration $\left(0.008 \mathrm{mg} \mathrm{L}^{-1}\right)$, high concentration of copper $\left(20.0 \mathrm{mg} \mathrm{L}^{-1}\right)$, low concentrations of iron $\left(0.219 \mathrm{mg} \mathrm{L}^{-1}\right)$, nickel $\left(0.457 \mathrm{mg} \mathrm{L}^{-1}\right)$, zinc and detergents (both concentrations are below the quantification limit).

\subsection{Methods}

\subsubsection{Peanut hulls characterization}

The chemical characterization of peanut hulls was performed after grinding and sieving to pass a screen of $1 \mathrm{~mm}$. The following parameters were measured: dry matter was determined by drying samples in a forced-air oven at $65^{\circ} \mathrm{C}$; ash content was evaluated in a muffle furnace at $550^{\circ} \mathrm{C}$ for $8 \mathrm{~h}$ (AOAC, 1990); organic matter was calculated by subtracting ash from dry matter; crude protein, considered as N Kjeldahl x 6.25, was obtained according to AOAC (1990); crude fat was determined by extraction with petroleum ether, using a Gerhart Soxtherm 2000 Automatic system; neutral detergent fibre (NDF), acid detergent fibre (ADF), and acid detergent lignin (ADL) were analyzed by the method of Van Soest et al. (1991); hemicellulose and cellulose were calculated as the differences between NDF and ADF, and between ADF and ADL, respectively.

\subsubsection{Determination of metal concentration}

Metal concentration was evaluated by atomic absorption spectrophotometry (AAnalyst 200, Perkin Elmer Instruments) and pH was measured with a pH meter (Crison, GLP22).

\subsubsection{Batch studies}

The kinetic studies were performed at $\mathrm{pH} 4.1$ and $20^{\circ} \mathrm{C}$, using a metal solution with $20 \mathrm{mg} \mathrm{L}^{-1}$ initial concentration ( $900 \mathrm{~mL}$ of total volume) and $4 \mathrm{~g} \mathrm{~L}^{-1}$ sorbent concentration. Magnetic stirring at 400 rpm (Nahita, Model 690/1) was used and samples were taken during the experiments, along 180 min. $\mathrm{pH}$ was measured continuously. After filtering the samples (cellulose acetate fibre filters, $0.45 \mu \mathrm{m}$ pore size diameter, Albet AC-045-47), the metal concentration was evaluated. 
The influence of $\mathrm{pH}$ was evaluated in the range 3 to 6 using the same conditions. A set of $100 \mathrm{~mL}$ erlenmeyers (with cap) containing $50.00 \mathrm{~mL}$ of solution and $0.2 \mathrm{~g}$ of peanut hulls was used. Agitation was performed at $400 \mathrm{rpm}$ using a magnetic stirrer (Velp, Multi 15 stirrer) into a refrigerated incubator (P-Selecta Hotcold-M). All experiments were made in duplicate and a control test (without sorbent) was run for each metal solution. At the end, samples were filtrated, then metal concentration and $\mathrm{pH}$ were measured.

The equilibrium isotherms were determined at $\mathrm{pH} 5$, using the same experimental procedure that was used for the $\mathrm{pH}$ studies, except that different amounts of peanut hulls were used in each flask (0.01 to $0.25 \mathrm{~g}$ ).

\subsubsection{Column studies}

Column experiments were performed using a packed jacketed column, working at $20^{\circ} \mathrm{C}$ (tap water was used as thermostatic fluid). The metal solution was pumped (Gilson, Miniplus 3) downflow through the glass column (Omnifit), with $2.5 \mathrm{~cm}$ inside diameter and $15 \mathrm{~cm}$ height, at a $5 \mathrm{~cm}^{3} \mathrm{~min}^{-1}$ flowrate. After weighing $10 \mathrm{~g}$ of peanut hulls, the sorbent was immersed in distilled water and the air in the adsorbent pores was removed by a vacuum pump, to allow a full contact sorbent/metal solution. The material was then placed inside the column. The inlet metal concentration was $20 \mathrm{mg} \mathrm{L}^{-1}$; samples were collected at the column outlet, allowing the determination of the metal concentrations and $\mathrm{pH}$.

\section{RESULTS}

Kinetic, equilibrium and column studies were performed for copper (II), nickel (II) and zinc (II), in mono-component and tri-component systems. Experiments with a real industrial effluent from the electroplating industry were also carried out.

Most of concentrations are presented in $\mathrm{m} \mathrm{L} \mathrm{L}^{-1}$ in order to allow a future comparison with legal limits of discharge, therefore sorption capacities are presented in $\mathrm{mg} \mathrm{g}^{-1}$. Capacities in $\mathrm{mmol} \mathrm{g}^{-1}$ were calculated when a comparison between metals affinity was needed.

The software Fig.P, version 2.98, was used for the non-linear adjustment to models. The statistic treatment allowed the determination of the confidence intervals at $95 \%$ for each parameter of the model, the variance $\left(\mathrm{s}^{2}\right)$, and the determination factor $\left(\mathrm{r}^{2}\right)$ for each model fit. A Fisher's test was performed in order to compare models, based on the $F$-values for the models $\left(F_{\text {calc }}\right)$ and $F$ critics $\left(F_{c}\right)$ for a probability value of $95 \%$.

\subsection{Chemical characterization}

The chemical characterization of peanut hulls allowed the determination of the following parameters: $92 \%$ of organic matter; $3.8 \%$ of ash content; $5.4 \%$ of crude protein; $0.1 \%$ of crude fat; $36.1 \%$ of lignin; $5.6 \%$ of hemicellulose and $44.8 \%$ of cellulose. The results obtained are in accordance with other characterizations (Brown et al., 2000; Yang, 2005).

Basso et al. (2002) suggested that there is a correlation between lignin content of several lignocelluloses and their ability to remove heavy metals from aqueous solutions. Therefore the high cellulose and lignin content observed favour biosorption of metal ions.

Moreover, lignocellulosic materials are very porous, have a very high specific surface area and affinity for water (Pehlivan et al., 2008), which improve the performance of these materials as sorbents. Cellulosic surface becomes partially negatively charged when immersed in water so that possesses columbic interaction with cationic species, which contributes to the high binding abilities of these materials, especially divalent metal cations (Laszlo and Dintzis, 1994). The oxygen of each carbonyl (present in fats, lignin, protein and pectin) and hydroxyl group (present in cellulose and lignin) is considered a strong Lewis base because of the presence of its vacant double electrons, which could bind to a metal cation forming a complex of coordination.

\subsection{Batch equilibrium and kinetic studies}

The experimental results of the kinetic studies are presented in Figure 1 for mono (a) and tricomponent (b) systems. During the kinetic studies the $\mathrm{pH}$ change was not considered significant, it has increased from 4.1 to 4.5 . 

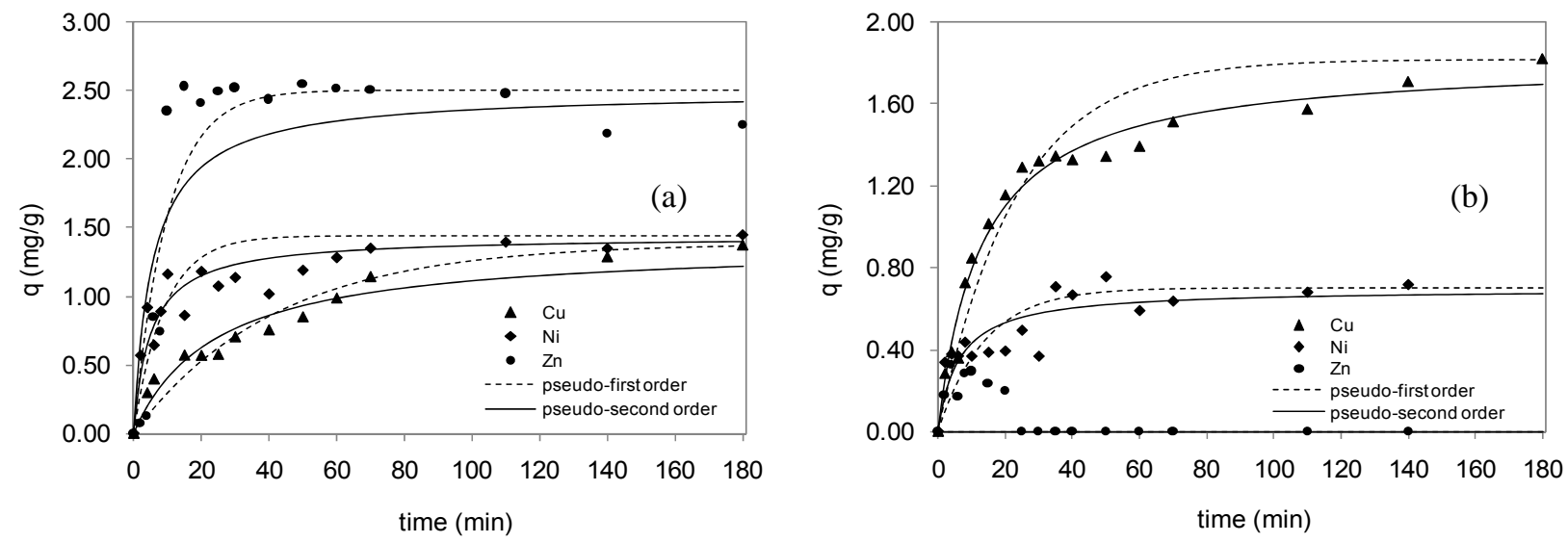

Figure 1. Kinetic studies for $\mathrm{Cu}(\mathrm{II}), \mathrm{Ni}(\mathrm{II})$ and $\mathrm{Zn}(\mathrm{II})$ in mono (a) and tri-component(b) systems; pseudo-first and pseudo-second order models fits

In mono-component systems, biosorption rapidly increased in the first $30 \mathrm{~min}$, after which slowly approached equilibrium. At this time about $50 \%$ of copper, $80 \%$ of nickel and $100 \%$ of zinc have been removed, when compared with the total amount removed at equilibrium. In mono-component systems, zinc reached equilibrium after $1 \mathrm{~h}$, and nickel and copper after $2 \mathrm{~h}$. Other researchers (Zhu et al., 2008) obtained similar results for copper removal by the same material. The same equilibrium times were observed in tri-component system, however the amount removed of each metal was lower. The Lagergren's (1898) pseudo-first and Ho's (1995) pseudo-second order models were fitted to the experimental data. The model parameters and their statistics are presented in Table 1. The Fisher's test indicates that for copper the models are statistically equivalent for mono-component system and, considering their high determination coefficients, any model could be used; for the tricomponent system, the best fit was obtained for the pseudo-second order model; this kinetic model was proposed for the same system by Zhu et al. (2008).

The pseudo-second order model was also the best for nickel in mono component system; for the same metal, in tri-component system, the models are statistically equivalent, however presenting lower determination coefficients than for copper.

For zinc, only the mono-component system data could be fitted; the models are statistically equivalent but the determination coefficients are not high.

Pseudo-second order kinetics was followed in general. Other researchers also report the same kinetics for metals removal by agricultural wastes (Aydin et al., 2008).

From Table 1, it can be calculated that the total sorption of metals $\left(0.041 \mathrm{mmol} \mathrm{g}^{-1}\right)$ was similar to the maximum capacity obtained in mono-component system $\left(0.038 \mathrm{mmol} \mathrm{g}^{-1}\right.$ for zinc).

Table 1. Parameters of the kinetic models for the sorption of $\mathrm{Cu}(\mathrm{II}), \mathrm{Ni}(\mathrm{II})$ and $\mathrm{Zn}(\mathrm{II})$

in mono and tri-component systems

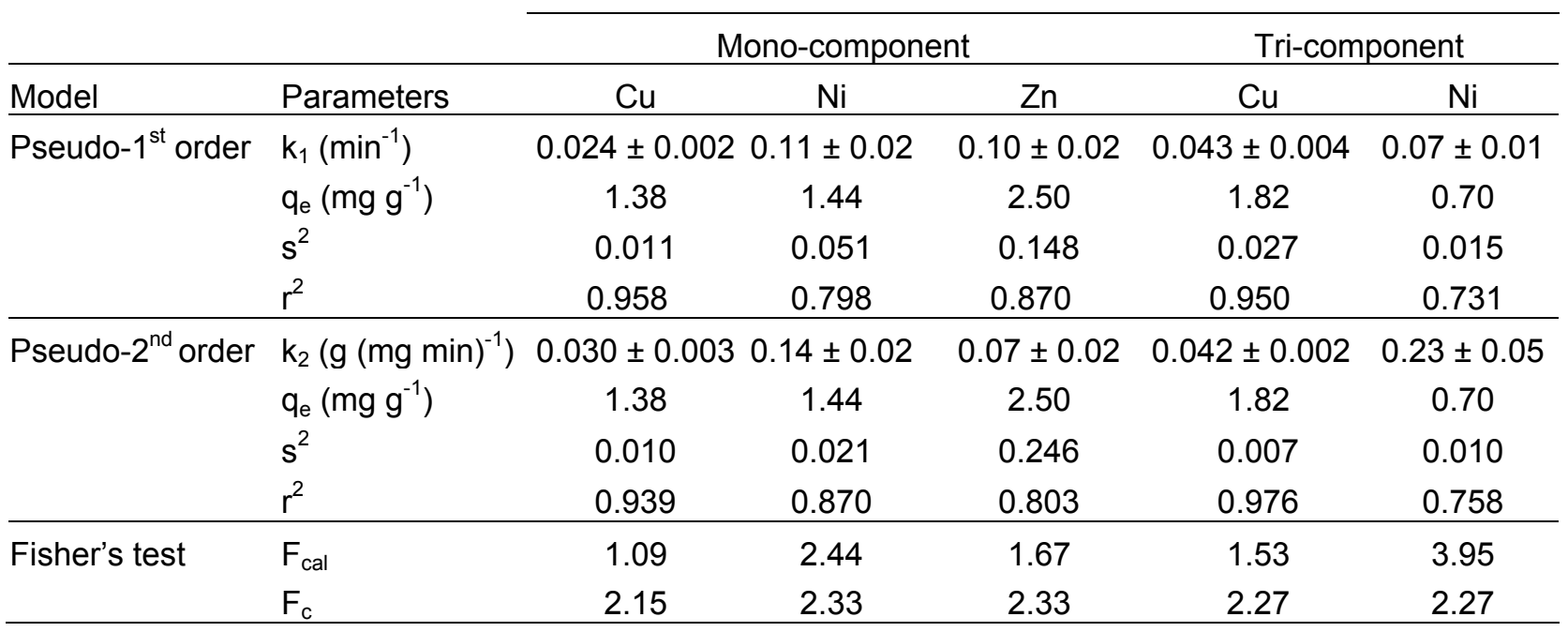


The study of $\mathrm{pH}$ influence was performed in the range 3-6, based on previous studies (Aydin et al., 2008; Pehlivan et al., 2008; Zhu et al., 2008). For higher $\mathrm{pH}$ values, the sharp decrease of adsorption is due to the beginning of hydroxides precipitation.

Figure 2 shows that the sorption capacity strongly increased with $\mathrm{pH}$ in the range 3-4. The same effect was observed by Zhu et al. (2008) who explain that it is because the point of zero charge for peanut hull is about 3.5. At $\mathrm{pH}$ values higher than 4 , the change in capacity values is not significant for copper and nickel; for zinc, there is an increase in metal ions uptake as the $\mathrm{pH}$ value increases from 3 to 6 , which could be explained because at lower $\mathrm{pH}$ values, the $\mathrm{H}_{3} \mathrm{O}^{+}$ions compete with the metal ions for the exchange sites in the adsorbent. $\mathrm{A} \mathrm{pH}$ value between 5 and 6 was considered the most favourable for all systems according to the results presented in Figure 2. These findings were also reported in the cited studies for metal divalent ions removal using agricultural wastes.

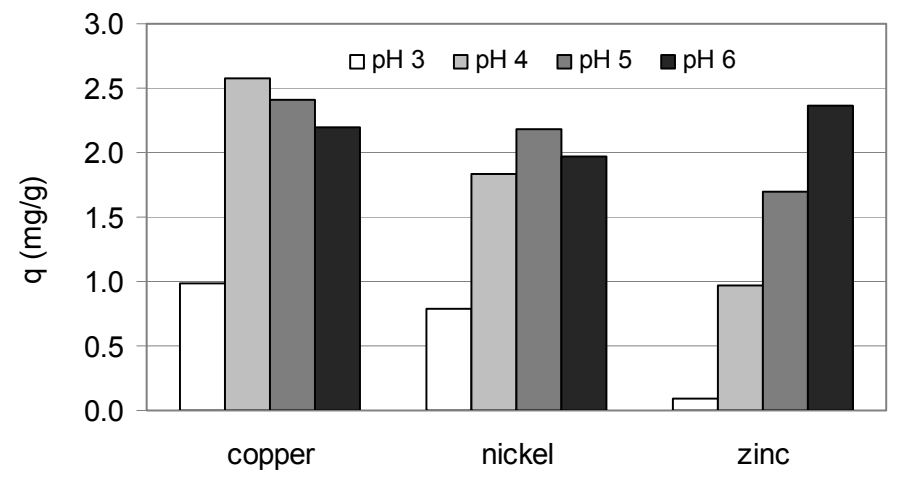

Figure 2. Effect of $\mathrm{pH}$ on the biosorption of $\mathrm{Cu}(\mathrm{II}), \mathrm{Ni}(\mathrm{II})$ and $\mathrm{Zn}(\mathrm{II})$ by peanut hulls

The experimental results of the equilibrium studies, performed at $\mathrm{pH} 5$, are presented in Figure 3 for mono (a) and tri-component (b) systems.

The Freundlich (1906) model, one of the models commonly used to describe the biosorption, was employed to study the process. The model described both the mono-component systems for all metals and the tri-component system for copper; this model could not fit the nickel and zinc isotherms in tri-component system. The model parameters and their statistics are shown in Table 2. The same model has been used by Zhu et al. (2008) to represent sorption of copper on peanut hulls, showing favourable sorption $(n>1)$. The same was observed, in this study, for copper in monocomponent system, however in tri-component system its sorption is unfavourable. All the other systems studied show (Figure 3, Table 2) also unfavourable isotherms, both in mono-component and tri-component systems.
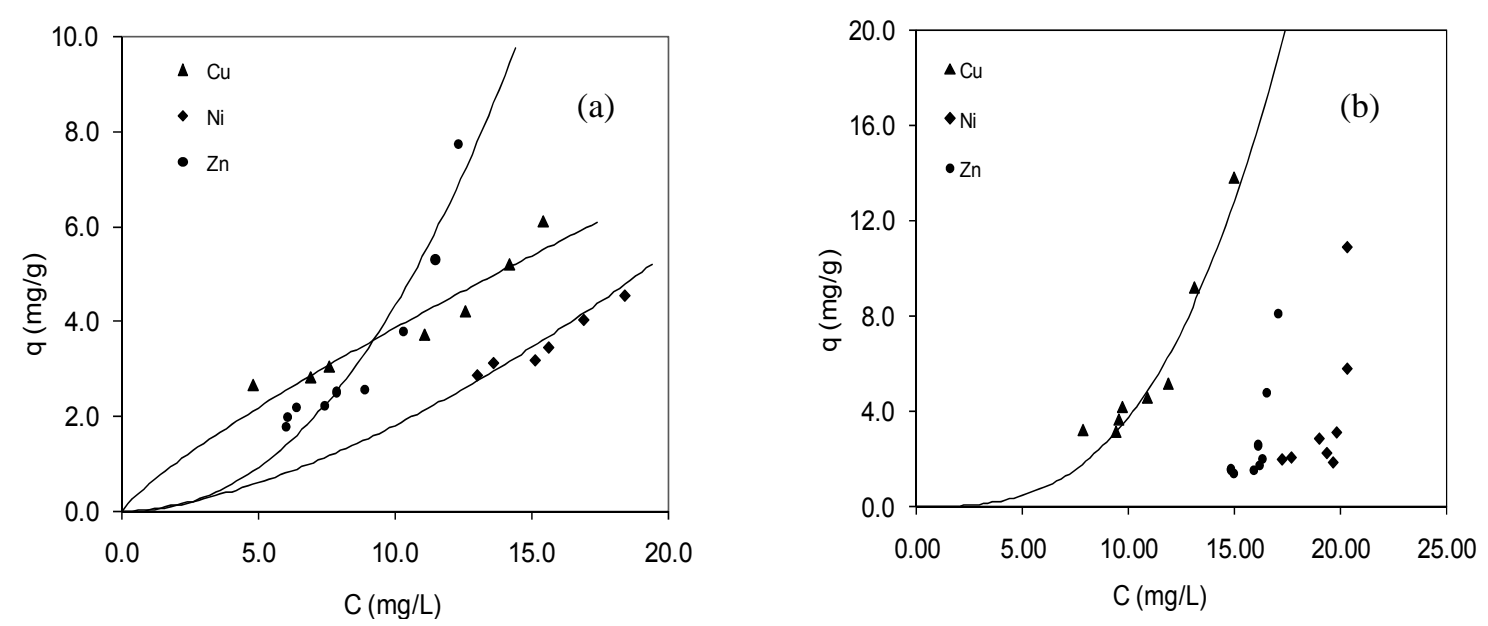

Figure 3. Equilibrium studies for $\mathrm{Cu}(\mathrm{II}), \mathrm{Ni}(\mathrm{II})$ and $\mathrm{Zn}(\mathrm{II})$ in mono (a) and tri-component (b) systems and Freundlich model fits 
The sorption capacities evaluated at the equilibrium concentration of $15 \mathrm{mg} \mathrm{L}^{-1}$ (Figure 3 ) for copper, nickel and zinc in tri-component system are $0.218,0.185$ and $0.123 \mathrm{mmol} \mathrm{g}^{-1}$, respectively. These results might indicate that peanut hulls have a higher affinity for copper than for nickel and zinc, when they are both present. The same behaviour was observed in tri-component kinetic studies (Figure 1, Table 1).

Table 2. Parameters of the Freundlich model for the sorption of $\mathrm{Cu}(\mathrm{II}), \mathrm{Ni}(\mathrm{II})$ and $\mathrm{Zn}(\mathrm{II})$ in mono and tri-component systems

\begin{tabular}{lcccc} 
& \multicolumn{3}{c}{ Mono-component } & Tri-component \\
\cline { 2 - 5 } Parameters & $\mathrm{Cu}$ & $\mathrm{Ni}$ & $\mathrm{Zn}$ & $\mathrm{Cu}$ \\
\hline $\mathrm{K}_{\mathrm{F}}\left(\left(\mathrm{mg} \mathrm{g}^{-1}\right)\left(\mathrm{L} \mathrm{mg}^{-1}\right)^{1 / \mathrm{n}}\right)$ & $0.6 \pm 0.2$ & $0.05 \pm 0.02$ & $0.03 \pm 0.02$ & $0.004 \pm 0.002$ \\
$\mathrm{n}$ & $1.2 \pm 0.2$ & $0.63 \pm 0.05$ & $0.45 \pm 0.06$ & $0.33 \pm 0.03$ \\
$\mathrm{~s}^{2}$ & 0.182 & 0.063 & 0.395 & 0.694 \\
$\mathrm{r}^{2}$ & 0.955 & 0.984 & 0.962 & 0.964 \\
\hline
\end{tabular}

\subsection{Column studies}

Tri-component column studies were performed in order to evaluate the influence of the simultaneous presence of the three metals, which may occur in real industrial effluents. As verified in batch equilibrium and kinetic studies, copper shows a higher affinity than nickel and zinc for peanut hulls, therefore a column experiment with copper in mono-component system was performed for comparison with tri-component system.

The results of the fixed bed column experiments are represented in Figure 4 as the history of the metal outlet concentration normalized by the inlet concentration for copper in mono (a) and tricomponent (b) systems.
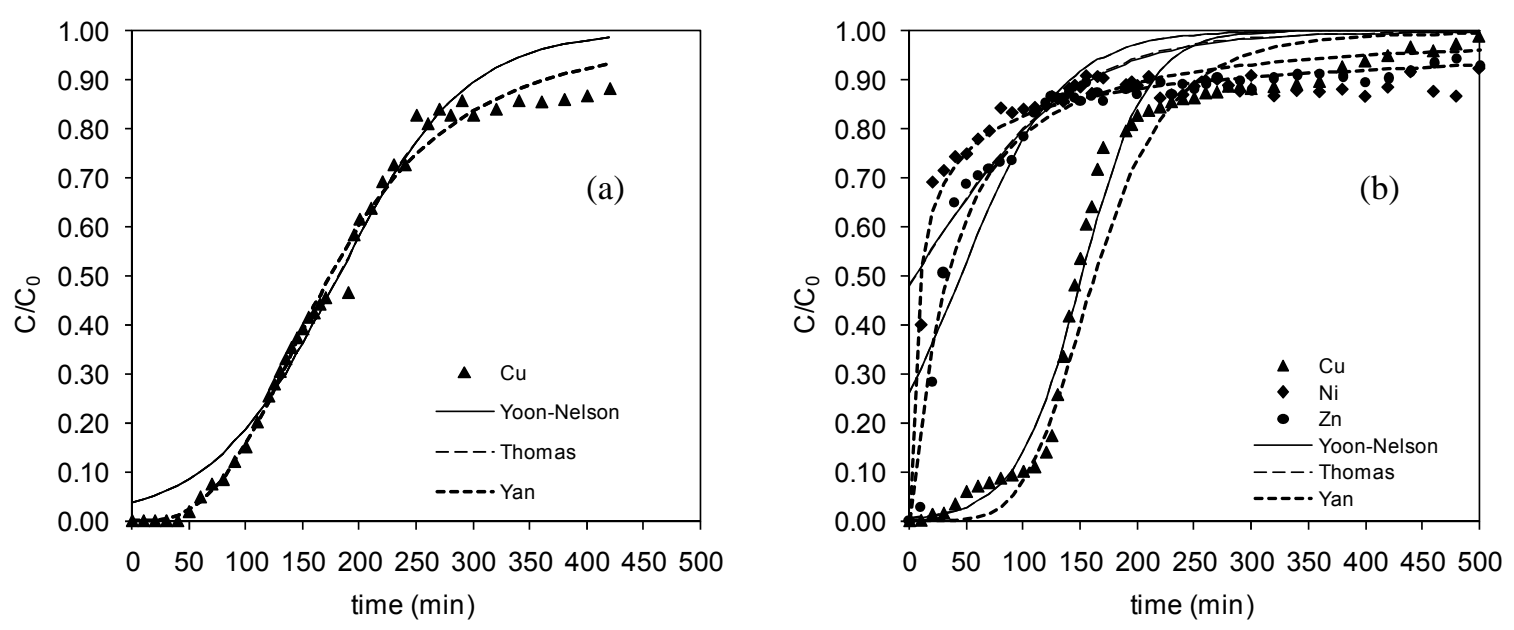

Figure 4. Column studies for $\mathrm{Cu}(\mathrm{II}), \mathrm{Ni}(\mathrm{II})$ and $\mathrm{Zn}(\mathrm{II})$ in mono (a) and tri-component (b) system; Yoon-Nelson, Thomas and Yan's model fits

The Yoon-Nelson (1984), Thomas (1944) and Yan's (2001) models were fitted to the experimental data. The best fit to the experimental breakthrough curve was obtained for Yan's model, as demonstrated by the Fisher's test values. However there is some lack of fit in the period 50-100 min (Figure 4). The parameters and their statistics are presented in Table 3. 
Table 3. Parameters of the column models for the sorption of $\mathrm{Cu}(\mathrm{II}), \mathrm{Ni}(\mathrm{II})$ and $\mathrm{Zn}(\mathrm{II})$ in mono and tri-component system

\begin{tabular}{llcccc} 
& & Mono-component & & Tri-component \\
\cline { 2 - 6 } Model & Parameters & $\mathrm{Cu}$ & $\mathrm{Cu}$ & $\mathrm{Ni}$ & $\mathrm{Zn}$ \\
\hline Yoon-Nelson & $\mathrm{k}_{\mathrm{YN}}\left(\mathrm{min}^{-1}\right)$ & $0.0180 \pm 0.0009$ & $0.035 \pm 0.003$ & $0.014 \pm 0.003$ & $0.023 \pm 0.003$ \\
$(\mathrm{YN})$ & $\mathrm{T}_{\mathrm{YN}}(\mathrm{min})$ & $182 \pm 3$ & $151 \pm 2$ & $5 \pm 14$ & $45 \pm 6$ \\
& $\mathrm{~s}^{2}$ & 0.0029 & 0.0049 & 0.012 & 0.010 \\
& $\mathrm{r}^{2}$ & 0.978 & 0.979 & 0.580 & 0.835 \\
\hline Thomas & $\mathrm{k}_{\mathrm{TH}}\left(\mathrm{mL}\left(\mathrm{mg} \mathrm{min}^{-1}\right)\right.$ & $0.86 \pm 0.04$ & $1.7 \pm 0.1$ & $0.7 \pm 0.1$ & $1.2 \pm 0.2$ \\
$(\mathrm{~T})$ & $\mathrm{q}_{\mathrm{TH}}\left(\mathrm{mg} \mathrm{g}^{-1}\right)$ & $1.90 \pm 0.03$ & $1.61 \pm 0.02$ & $0.07 \pm 0.14$ & $0.45 \pm 0.06$ \\
& $\mathrm{~s}^{2}$ & 0.003 & 0.005 & 0.012 & 0.010 \\
& $\mathrm{r}^{2}$ & 0.978 & 0.979 & 0.588 & 0.835 \\
\hline Yan & $\mathrm{a}_{\mathrm{Y}}$ & $3.01 \pm 0.09$ & $5.0 \pm 0.3$ & $0.64 \pm 0.04$ & $1.20 \pm 0.06$ \\
$(\mathrm{Y})$ & $\mathrm{q}_{\mathrm{Y}}\left(\mathrm{mg} \mathrm{g}^{-1}\right)$ & $1.81 \pm 0.02$ & $1.59 \pm 0.02$ & $0.09 \pm 0.01$ & $0.33 \pm 0.02$ \\
& $\mathrm{~s}^{2}$ & 0.00095 & 0.0036 & 0.0011 & 0.0018 \\
& $\mathrm{r}^{2}$ & 0.991 & 0.981 & 0.953 & 0.961 \\
\hline Fisher's test & $\mathrm{F}_{\mathrm{Cal}}(\mathrm{YN}-\mathrm{Y} ; \mathrm{T}-\mathrm{Y})$ & 3.07 & 1.38 & 11.01 & 5.73 \\
& $\mathrm{~F}_{\mathrm{C}}$ & 1.69 & 1.60 & 1.60 & 1.60 \\
\hline
\end{tabular}

The experimental breakthrough times, for $50 \%$ removal, were 10,40 and $150 \mathrm{~min}$, respectively for nickel, zinc and copper, which are in accordance with the Yoon-Nelson parameter, TYN (Table 3), and with the kinetic constants shown in Table 1. From Table 3, it can be calculated that the sorbent capacity for copper, estimated by Yan's model, $\mathrm{q}_{\mathrm{Y}}$, was 0.028 and $0.025 \mathrm{mmol} \mathrm{g}^{-1}$, respectively in mono and tri-component system, showing that copper was poorly influenciated by the presence of other metals. The total sorbent capacity estimated from the tri-component system, $0.032 \mathrm{mmol} \mathrm{g}^{-1}$, is quite similar to the mono-component sorption of $\mathrm{Cu}$ (II).

The affinity relation between metals and the peanut hulls in column studies was the same that was observed in batch studies. Copper is the most acidic ion and is the least affected by the presence of other less acidic metals, influencing the other metal uptake (Pagnanelli et al., 2002), which was related to their hydrolysis constants $\left(\log \mathrm{K}_{\mathrm{Cu}}=-8.00>\log \mathrm{K}_{\mathrm{Zn}}=-8.96>\log \mathrm{K}_{\mathrm{Ni}}=-9.68\right)$ (Schiever, 1996). Nickel and zinc presented similar behaviour, being the latter better removed.

\subsection{Experiments with a real effluent}

Kinetic, equilibrium and column experiments were performed with peanut hulls using a real industrial effluent from the electroplating industry, containing copper in order to compare them with the results obtained in mono and tri-component system.

The kinetic experiments (data not presented) show that equilibrium was reached earlier than in mono and tri-component experiments, which took only $30 \mathrm{~min}$.

The equilibrium isotherm results were fitted by Freundlich model, as it has been done for the other systems with copper. The model parameters obtained (Table 4) cannot be compared directly because this experiment was performed at the original $\mathrm{pH}, 7.0$.

Table 4. Parameters of the Freundlich model for the sorption of $\mathrm{Cu}(\mathrm{II})$ in real effluent system

\begin{tabular}{|c|c|}
\hline \multirow{2}{*}{ Parameters } & Real Effluent, $\mathrm{pH}=7.0$ \\
\hline & $\mathrm{Cu}$ \\
\hline $\mathrm{K}_{\mathrm{F}}\left(\left(\mathrm{mg} \mathrm{g}^{-1}\right)\left(\mathrm{L} \mathrm{mg}^{-1}\right)^{1 / \mathrm{n}}\right)$ & $3.7 \pm 1.2$ \\
\hline$n$ & $8.4 \pm 10.2$ \\
\hline$s^{2}$ & 0.210 \\
\hline$r^{2}$ & 0.934 \\
\hline
\end{tabular}


The column experiments, performed both at the original $\mathrm{pH}(7.0)$ and at the $\mathrm{pH}$ selected for this work (5.0), are compared in Figure 5 with the tri-component results from Figure 4 . The same column models were fitted to the experimental results and their parameters are presented in Table 5 . The Fisher's test shows that the Yan's model is the best fit for the real effluent tested at $\mathrm{pH} 5.0$; for $\mathrm{pH}$ 7.0 the three models are statistically equivalent.

Comparing the sorption capacities of copper estimated by Yan's model in tri-component system (Tables 3 and 5) and in the industrial effluent, it can be seen that there is a significant decrease in capacity (around 50\%) in the last case. This may be related with the presence of other substances in the wastewater, which has a more complex constitution than the tri-component system.

From Yoon-Nelson's model, when comparing $T_{Y N}$ in mono and tri-component systems, respectively 182 and $151 \mathrm{~min}$ (Table 3), it is longer in the first case as expected, due to the presence of the other metals. This parameter has decreased to $83 \mathrm{~min}$, for the real effluent at $\mathrm{pH} 5.0$, probably due to the increased complexity of real effluent. However, at pH 7.0 the $T_{Y N}$ is higher than these values, 209 min, which may be related with the beginning of hydroxides precipitation reported for $\mathrm{pH}$ values higher than 6 . The influence of $\mathrm{pH}$ in the capacity is significant in the range 5-7 (Table 5) and is higher $17 \%$ at $\mathrm{pH} 7.0$.

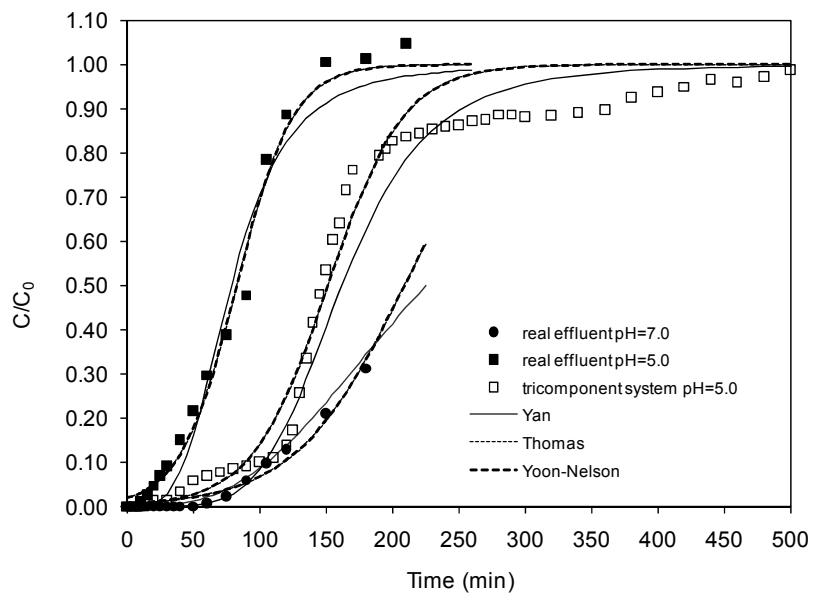

Figure 5. Column studies for the real effluent, at $\mathrm{pH} 5$ and 7, and for the tri-component system; Yoon-Nelson, Thomas and Yan's model fits

Table 5. Parameters of the column models for the sorption of $\mathrm{Cu}(\mathrm{II})$ in real effluent system

\begin{tabular}{llcc} 
& & \multicolumn{2}{c}{ Real effluent } \\
\cline { 3 - 4 } Model & Parameters & $\mathrm{pH}=7$ & $\mathrm{pH}=5$ \\
\hline Yoon-Nelson & $\mathrm{k}_{\mathrm{YN}}\left(\mathrm{min}^{-1}\right)$ & $0.024 \pm 0.003$ & $0.047 \pm 0.003$ \\
$(\mathrm{YN})$ & $\mathrm{T}_{\mathrm{YN}}(\mathrm{min})$ & $209 \pm 4$ & $83 \pm 2$ \\
& $\mathrm{~s}^{2}$ & $2.38 \times 10^{-4}$ & $1.65 \times 10^{-3}$ \\
& $\mathrm{r}^{2}$ & 0.976 & 0.992 \\
\hline Thomas & $\mathrm{k}_{\mathrm{TH}}\left(\mathrm{mL}^{2}(\mathrm{mg} \mathrm{min})\right.$ & $3.2 \pm 0.2$ & $2.5 \pm 0.2$ \\
$(\mathrm{~T})$ & $\mathrm{q}_{\mathrm{TH}}\left(\mathrm{mg} \mathrm{g}^{-1}\right)$ & $0.79 \pm 0.02$ & $0.78 \pm 0.02$ \\
& $\mathrm{~s}^{2}$ & $2.38 \times 10^{-4}$ & $1.65 \times 10^{-3}$ \\
& $\mathrm{r}^{2}$ & 0.976 & 0.992 \\
\hline Yan & $\mathrm{a}_{\mathrm{Y}}$ & $2.91 \pm 0.08$ & $3.6 \pm 0.4$ \\
$(\mathrm{Y})$ & $\mathrm{q}_{\mathrm{Y}}\left(\mathrm{mg} \mathrm{g}^{-1}\right)$ & $0.89 \pm 0.01$ & $0.76 \pm 0.03$ \\
& $\mathrm{~s}^{2}$ & $3.36 \times 10^{-5}$ & $3.95 \times 10^{-3}$ \\
& $\mathrm{r}^{2}$ & 0.996 & 0.981 \\
\hline Fisher's test & $\mathrm{F}_{\text {cal }}(\mathrm{YN}-\mathrm{Y} ; \mathrm{T}-\mathrm{Y})$ & 7.08 & 2.39 \\
& $\mathrm{~F}_{\mathrm{C}}$ & 2.56 & 2.72 \\
\hline
\end{tabular}




\section{CONCLUSIONS}

This research work indicates that peanut hull is a promising sorbent material for metals removal copper (II), nickel (II) and zinc (II) - specially for copper that can efficiently be removed both in mono-component and tri-component systems, in batch continuous stirred tank adsorber and in column. Tri-component studies were an approach to real industrial wastewaters with their complexity, which is one of the challenges in the treatment of real effluents. The experiments with a real industrial effluent from electroplating industry suggest the applicability of peanut hulls for copper removal even though a decrease capacity and breakthrough time was observed in column studies.

\section{REFERENCES}

AOAC - Association of Official Analytical Chemists (1990) Official Methods of Analysis, vol. I, 15th ed. AOAC, Arlington, VA.

Aydin H., Bulut Y. and Yerlikaya Ç. (2008) Removal of copper (II) from aqueous solution by adsorption onto low-cost adsorbents, J. Environ. Manage., 87, 37-45.

Basso M. C., Cerrella E. G. and Cukierman A. L. (2002) Lignocellulosic materials as potential biosorbents of trace toxic metals from wastewaters, Ind. Eng. Chem. Res., 41(15) 3580-3585.

Brown P., Jefcoat I. A., Parrish D., Gill S. and Graham E. (2000) Evaluation of the adsorptive capacity of peanut hull pellets for heavy metals in solution, Adv. Environ. Res., 4(1), 19-29.

Freundlich H. M. F. (1906) Über die adsorption in läsungen, Zeitschrift für Physikalische Chemie, 57, 385470.

Ho Y.S. (1995) Absorption of heavy metals from waste streams by peat, Ph.D. Thesis, University of Birmingham, UK, 1995.

Lagergren S. (1898) Zur theorie der sogenannten adsorption gelöster stoffe, Kungliga Svenska Vetenskapsakademiens Handlingar, 24(4), 1-39.

Laszlo J. A. and Dintzis F. R. (1994) Crop residues as ion-exchange materials: Treatment of soybean hull and sugar beet fiber (pulp) with epichlorohydrin to improve cation-exchange capacity and physical stability, J. Appl. Poly. Sci., 52, 531-538.

Pagnanelli F., Esposito A. and Vegliò F. (2002) Multi-metallic modelling for biosorption of binary systems, Water Res., 36, 4095-4105.

Pehlivan E., Altun T., Cetin S., Bhangher M. I. (2008) Lead sorption by waste biomass of hazelnut and almond shell, J. Hazard. Mater. (doi: 10.1016/j.jhazmat.2009.01.126)

Reddad Z., Gérente C., Andrès Y. and Cloirec P. (2002) Adsorption of Several Metal lons onto a LowCost Biosorbent: Kinetic and Equilibrium Studies, Environ. Sci. Technol., 36, 2067-2073.

Schiever S. (1996) Multi-metal ion exchange in biosorption, PhD. Thesis, Department of Chemical Engineering, McGill University, Montreal, Canada.

Sud D., Mahajan G and Kaur N. P. (2008) Agricultural waste material as potential adsorbent for sequestering heavy metal ions form aqueous solutions - A review, Bioresour. Technol., 99, 60176027.

Thomas H.C. (1944) Heterogeneous ion exchange in a flowing system, J. Am. Chem. Soc., 66, 16641666.

Van Soest P.J., Robertson J.B. and Lewis B.A. (1991) Methods for dietary fiber, neutral detergent fiber, and nonstarch polysaccharides in relation to animal nutrition, J. Dairy Sci., 74, 3583-3597.

Yan G. and Viraraghavan T. (2001) Heavy metal removal in a biosorption column by immobilized M. rouxii biomass, Bioresour. Technol., 78(3), 243-249.

Yang C.-M.J. (2005) Soybean milk residue ensiled with peanut hulls: fermentation acids, cell wall composition, and silage utilization by mixed ruminal microorganisms, Bioresour. Technol., 96, 14191424.

Yoon Y. H. and Nelson J. H. (1984) Aplication of gas adsorption kinetics. I. A theoretical model for respirator cartridge service time, Am. Ind. Hyg. Assoc. J., 45, 509-516.

Zhu C.-S., Wang L.-P. and Chen W.-B. (2008) Removal of Cu (II) from aqueous solution by agricultural by-product: Peanut hull, J. Hazard. Mater., 168, 739-746. 